\title{
Biomass production and stool mortality in hybrid poplar coppiced twice a year
}

\author{
D Auclair ${ }^{1 *}$, L Bouvarel $2^{\star \star}$ \\ 1 INRA, Station de Sylviculture; \\ 2 INRA, Unité expérimentale biomasse forestière et forêt paysanne, Ardon, 45160 Olivet, France
}

(Received 4 October 1990; accepted 11 March 1992)

\begin{abstract}
Summary - In order to study the effects of extremely short rotations, the growth of hybrid poplar cuttings coppiced biannually over a period of 4 years, in summer and in winter, was compared with growth of cuttings coppiced annually in winter. The biannual treatment led to a progressive decrease in height growth and in total biomass production, and to high stool mortality. Some aspects of the physiology of coppicing are discussed.
\end{abstract}

growth / coppice / short rotation / Populus

Résumé - Production de biomasse et mortalité des souches de peuplier hybride recépé deux fois par an. Des boutures de peuplier hybride interaméricain recépées deux fois par an pendant 4 ans ont été comparées à des boutures recépées annuellement, dans le but d'étudier les effets d'un stress physiologique important sur la croissance des rejets de taillis. Le recépage bisannuel a entrainé une forte mortalité des souches et une baisse de la croissance en hauteur. Une diminution de la production de biomasse sèche par unité de surface peut être attribuée à la fois à une baisse de production en biomasse des souches vivantes et à la mortalité. Différents aspects du fonctionnement des arbres traités en taillis sont discutés.

croissance / taillis / courte rotation / Populus

\footnotetext{
" Present address: INRA, Laboratoire de Recherches Forestières Méditerranéennes, Avenue A Vivaldi, 84000 Avignon, France

** Present address: Station de Mécanique Forestière, Association Pour la Rationalisation et la Mécanisation de l'Exploitation Forestière, 45210 Fontenay sur Loing, France
} 


\section{INTRODUCTION}

Silviculture of coppice, practised since neolithic times in Europe (Evans, 1984), utilizes the ability of many broad-leaved trees to regenerate themselves from the cut stump. The early growth rate of coppice sprouts is much greater than that of seedlings or cutting (Lee et al, 1987; Wright, 1988; Bergez et al, 1989).

This very early peak of biomass annual increment, and the increasing demand for woody raw matter for industrial and energy use has induced foresters to decrease the length of coppice rotations, leading to the concept of short rotation intensive coppice (Perlack et al, 1986). The proposed short rotation usually ranges from 5 (Hummel et al, 1988) to 10 years (Bonduelle, 1990), compared to the traditional 20-30 years. Three-year rotations are practised in Sweden for energy forestry (Siren et al, 1987), and traditional basket-willow cultivation (Salix triandra and S viminalis) consists of 1-year rotations (Stott, 1956).

It is often speculated that rotations shorter than 3 years would entail yield losses after several rotations due to physiological problems, such as 'ageing' of the stumps and lack of carbohydrate reserves (Blake and Raitanen, 1981; Ferm et al, 1986). However, Auclair and Bouvarel (1992a) showed that hybrid poplar coppiced annually could maintain its production for at least 6 years. The end-product of such very short rotations is up to now still marginal, but some 1-year rotation systems are economically viable in particular cases.

The objective of the present experiment was to test the possibility of pursuing even further the shortening of the rotation. After the establishment year, young poplars were coppiced twice a year and their height growth and biomass production were compared with those coppiced only once a year. Total above-ground biomass production was analyzed, including leaves which might be of interest for wet biomass use, or for fodder.

\section{MATERIAL AND METHODS}

The present experiment was part of a larger project including different cutting cycles and planting densities (Auclair and Bouvarel, 1992a). One Populus trichocarpa $\times$ deltoides clone (Beaupré) was planted in spring 1983 on a converted woodland on the INRA estate near Orleans (central France). Situated on a loamy, gravelly ancient terrace of the Loire river, the sandy acid soil has a very low water and nutrient reserve. The temperate oceanic climate is characterized by annual precipitations of $600-700 \mathrm{~mm}$, summer water deficits, and mild mean temperatures $\left(18-21^{\circ} \mathrm{C}\right.$ in July, $2-4^{\circ} \mathrm{C}$ in January).

After harvesting and extracting the stumps of the previous crop (a mixed Quercus-BetulaCastanea coppice), the soil was ploughed and fertilized with phosphate, and rye was sown as an organic fertilizer in the autumn of 1982 . The rye was turned under and the planting bed harrowed in the spring of 1983 , before planting the cuttings.

Six individual plots of 400 cuttings, $30 \mathrm{~cm}$ long and 1-2 cm in diameter, were planted through plastic mulch in 3 randomized blocks, at $2.00 \times 0.25 \mathrm{~m}$ spacing, corresponding to 20000 cuttings per ha. After the establishment year, 3 replications were coppiced annually (treatment A), between February and April, and 3 replications were coppiced biannually (treatment $B$ ) as shown in table I.

During the first year, in order to ensure favourable establishment, the biannual treatment was not coppiced: both treatments followed the same management. After 1 year, survival was very high and the few dead stools $(2-3 \%)$ were replaced by new cuttings. There were no replacements in later years.

Management operations - irrigation, fertilization, weed and pest control - were identical to those described by Auclair and Bouvarel (1992b).

For each living stool, the height of the tallest shoot, called 'stool dominant height', and the 'number of dominants' (number of shoots higher than $75 \%$ of dominant height) were recorded at each harvest. In addition, stool dominant height 
Table I. Details of coppicing treatments given to short rotation coppice.

\begin{tabular}{clcc}
\hline Year & & Annual treatment & Biannual treatment \\
\hline 1 & $\begin{array}{l}\text { Spring 1983 } \\
\text { Winter 83-84 (March yr 2) }\end{array}$ & $\begin{array}{l}\text { Planting } \\
\text { Harvest }\end{array}$ & $\begin{array}{l}\text { Planting } \\
\text { Harvest } \\
\text { Harvest } \\
\text { Harvest }\end{array}$ \\
2 & $\begin{array}{l}\text { Summer 84 (July) } \\
\text { Winter 84-85 (March yr 3) }\end{array}$ & Harvest & $\begin{array}{l}\text { Harvest } \\
\text { Harvest } \\
\text { Harvest } \\
\text { Harvest }\end{array}$ \\
\hline
\end{tabular}

of plants in the annual treatment was recorded in July, to compare with the biannual treatment. The total fresh biomass produced by each stool was determined at the time of harvesting, and a sample of 15-30 stools per treatment was dried at $105^{\circ} \mathrm{C}$ to estimate dry woody biomass. Leaf dry biomass was determined on the sample harvested in summer, and on a sample of 15-30 stools in September, before leaf fall.

All statistical tests were performed at the $1 \%$ level. They were mainly restricted to $t$-tests applied to independent data sets each year. There was no border effect and no block effect (Auclair and Bouvarel, 1992a), consequently the data conceming height and number of dominants were expressed as means for each treatment. They did not include dead stools. Biomass data, expressed on a land area basis, included all stools.

\section{RESULTS AND DISCUSSION}

Stool mortality was quite high (10\%) after the first summer harvest of the biannual coppice, whereas it was only $1 \%$ for the annual treatment (fig 1). In subsequent years, mortality increased for both treatment, but it was most severe for stools coppiced biannually (32\% in year 3 ). After 4 years almost all stools in the biannual coppice had died, but $89 \%$ of the stools were still alive in the annual coppice.

Dominant height growth of living stools is shown in figure 2. Good growth was ob-

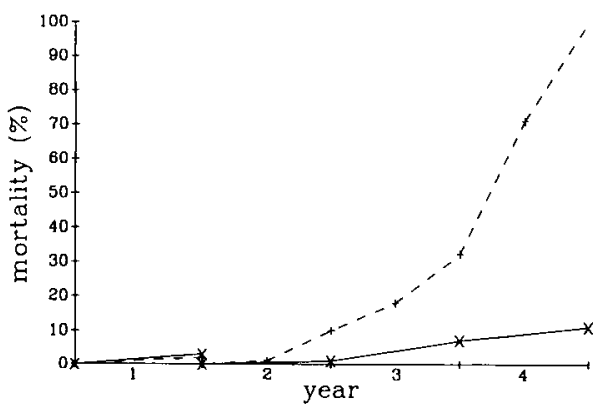

Fig 1. Percentage of poplar stumps, which failed to resprout after coppicing. $x \longrightarrow x$ : annual coppicing; +- - - + : biannual coppicing.

served in the first year in which irrigation was applied. In subsequent years, height growth was slightly depressed for the annual treatment, probably due to dry summer periods: average August rainfall was less than $40 \mathrm{~mm}$ for a total annual rainfall of $700 \mathrm{~mm}$. The spring period contributed most to total height growth of plants harvested annually, confirming the results of Bergez et al (1989).

In the biannual treatment, height growth progressively decreased from year 2 onwards. For both treatments, shoots grew taller during the spring period (measured in 


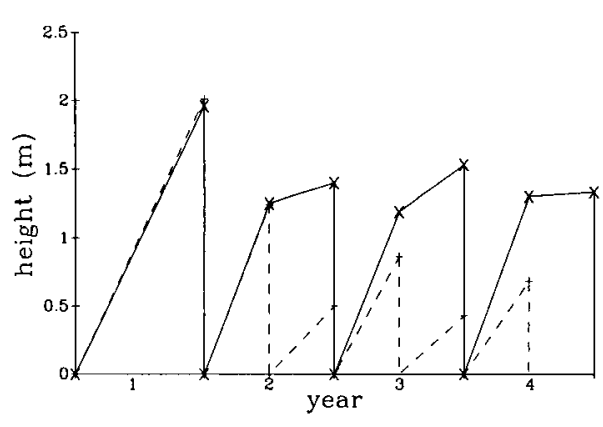

Fig 2. Average stool dominant height for coppiced poplar. $x \longrightarrow x$ : annual coppicing; +------+ : biannual coppicing.

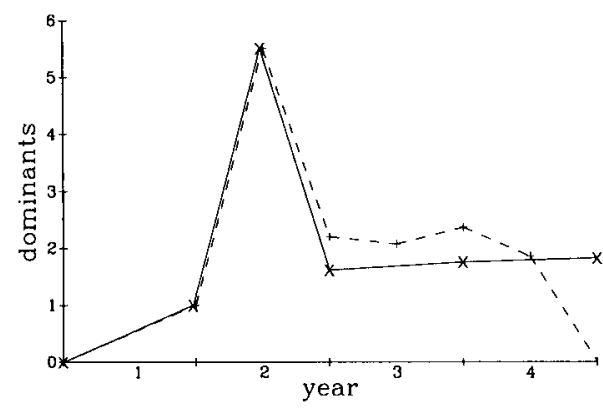

Fig 3. Average number of dominant shoots on stools of coppiced poplar 1 to 4 years after planting. $x \longrightarrow x$ : annual; +biannual coppicing.

July) than after the summer harvest in years 2-4 inclusive. This was probably due to the soil moisture deficits summer. However, plants in the biannual treatment had less height growth during the spring period, compared to plants in the annual treatment in years 3 and 4 . Differences between treatments for height growth were all statistically significant from year 2 onwards.

The number of dominant shoots per stool was very large (average of 5.5, ranging from 1-63) in July of year 2. It then de- creased to 1.6 shoots per stool in the annual treatment (fig 3 ): clearly competition within stools led to a very strong selection of shoots, and only 1-5 were dominant at the end of the second growing season. This was due mainly to the fact that few shoots produced much height growth after July; those which did became dominant. There was little mortality of the shoots by the end of the growing season. The number of dominants increased slightly each year for the annual treatment.

From year 2 until the end of the experiment, when most stools were dead, stools in the biannual treatment produced significantly larger numbers of dominants than those in the annual treatment, both in summer and in winter. The larger number of dominants in the biannual coppice than in the annual coppice can be attributed to the lack of competition between shoots from the same stool during the first period of growth. Competition began only after July in the annual treatment, when a small number of favoured shoots dominated the others. In the biannual treatment, competition was not great enough to induce such a selection.

Total above-ground production (leaf biomass plus wood biomass) was $380 \mathrm{~g} \cdot \mathrm{m}^{-2}$ in the first year, when both treatments had a single winter harvest. Each treatment produced approximately $250 \mathrm{~g}$ of wood and $130 \mathrm{~g}$ of leaves per square metre (fig 4).

In years $2-4$, the annual treatment produced less biomass than in the first year, a result highlighting the positive effect of irrigation in year 1 , in contrast to the dry conditions prevailing during summer in subsequent years (Auclair and Bouvarel, 1992a). Leaves accounted for about $35 \%$ of total biomass.

Biannual coppicing severely decreased total production. The winter harvest only yielded $20 \%$ of total annual biomass production. Leaves accounted for over $50 \%$ of 


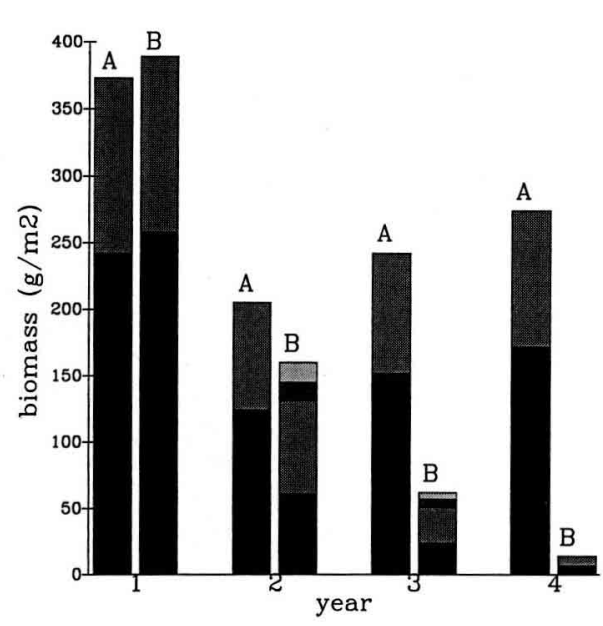

Fig 4. Total above-ground dry biomass production by coppiced poplar during 4 years following planting. Dark shade: woody biomass; light shade: leaves; A: annual coppicing; B: biannual coppicing; lower part: summer harvest; upper part: winter harvest. In the first year both treatments were harvested only once in winter.

total biomass. Total biomass production of the biannual treatment was $78 \%$ of the production of the annual treatment in the second year, $26 \%$ in the third year, and $5 \%$ in the fourth year. Differences between treatments were all statistically significant from the second year onwards.

It is interesting to note the relative contribution of stool mortality and of individual stool biomass to the decrease in production of the biannual treatment compared to the annual treatment (table II). Total dry woody biomass produced each year by living stools decreased in the biannual treatment compared to the annual treatment. The decrease in total woody biomass expressed on an area basis was even greater because of stool mortality in the biannual treatment.

It should be noted that growth ceased in mid-September for the annual treatment, but continued for another 2 weeks in the
Table II. Contribution of stool mortality and of individual living stool dry woody biomass to total biomass production in the biannual treatment, expressed as the percentage of the annual treatment.

\begin{tabular}{cccc}
\hline Year & Living stools & $\begin{array}{l}\text { Biomass } \\
\text { of living } \\
\text { stools }\end{array}$ & $\begin{array}{c}\text { Biomass } \\
\text { per unit } \\
\text { area }\end{array}$ \\
\hline & & & \\
1 & 101 & 105 & 107 \\
2 & 91 & 63 & 60 \\
3 & 73 & 23 & 19 \\
4 & $33^{*}$ & 12 & 4 \\
\hline
\end{tabular}

* In year 4 statistics were computed only for the July harvest, as mortality reached $100 \%$ in the biannual treatment at the end of the growing season.

biannual treatment. This was, however, insufficient to ensure a sustained production, and biomass production after the summer harvest was very low. This may be attributed to dry summer conditions which inhibited growth of the young sprouts. It is possible that the observed decrease in total annual production was caused by a depletion of stump reserves which would be utilized for both the spring and the summer budbreaks, and which could not be replaced during the summer period (Dubroca, 1983; Pontailler et al, 1984).

\section{CONCLUSION}

The aim of the present experiment was to study the possibility of coppicing trees with an extremely disturbing biannual cycle. The results clearly showed a decrease in biomass production and an increase in stool mortality in the biannual coppicing treatment.

In the absence of physiological studies on the present material, we can only spec- 
ulate on some aspects of the underlying physiology of coppiced trees. Summer harvests probably enhanced the coppicing stress by a loss of leaf area, preventing the buildup of carbohydrate reserves in the roots.

For further physiological studies, a sustained production could probably be obtained with additional irrigation and fertilization, although it would be uneconomical for pratical use. An analysis of root growth, such as that which was started by Bédéneau and Auclair (1989) using soil cores, or by using root growth chambers, could provide precious information on root-shoot relations in coppice. Below-ground and above-ground carbohydrate content, the pathways by which such reserves are built, and their allocation, water-use and nutrient uptake studies, such as those performed by Tschaplinski and Blake (1989a, 1989b), could be undertaken on experimental material such as ours, with different growth conditions, and should provide much information on the physiology of trees coppiced at more traditional rotations.

\section{ACKNOWLEDGMENTS}

This research was partly funded by the French Energy Management Agency (AFME). We are grateful to JD Isebrands, RE Dickson, And JD Deans for their helpful comments on the first version of the manuscript. We particularly wish to thank the technical staff of the Orléans silviculture and biomass laboratories.

\section{REFERENCES}

Auclair D, Bouvarel L (1992a) Influence of spacing and short rotations on Populus trichocarpa $\times$ deltoides coppice. Can J For Res 22 (in press)
Auclair D, Bouvarel L (1992b) Intensive or extensive cultivation of short rotation hybrid poplar coppice on forest land. Bioresource Technol 42 (in press)

Bédéneau M, Auclair D (1989) Effect of coppicing on hybrid poplar fine root dynamics. Ann Sci For 46 suppl, 294s-296s

Bergez JE, Auclair D, Bouvarel L (1989) First-year growth of hybrid poplar shoots from cutting or coppice origin. For Sci 35, 1105-1113

Blake TJ, Raitanen WE (1981) A Summary of Factors Influencing Coppicing. IEA Rep NE1981:22, Nat Swedish Board for Energy Source Dev, Stockholm, $24 \mathrm{p}$

Bonduelle $P$ (1990) Intensive cultivation of timber in short rotations. In: Biomass for Energy and Industry. 5th EC Conference (Grassi G, Gosse G, dos Santos G, eds) Elsevier Appl Sci, London, 1148-1154

Dubroca E (1983) Évolution saisonnière des réserves dans un taillis de châtaigniers, Castanea sativa Mill, avant et après la coupe. Thesis, Univ Paris-Sud, $209 \mathrm{p}$

Evans J (1984) Silviculture of Broadleaved Woodland. For Comm Bull 62, Her Majesty's Stationery Office, London, $232 \mathrm{p}$

Ferm A, Kauppi A, Rinne P (1986) Developing the coppicing potential of selected hardwoods in biomass energy production. In: Research in Forestry for Energy (Mitchell CP, Nilsson PO, Zsuffa L, eds) Swed Univ Agric Sci Garpenberg, Rep 49, 100-106

Hummel FC, Palz W, Grassi G (eds) (1988) Biomass Forestry in Europe: A Strategy for the Future. Elsevier Appl Sci, London, $600 \mathrm{p}$

Lee DK, Gordon JC, Promnitz LC (1987) Threeyear growth and yield of Populus hybrids grown under intensive culture. Biomass 13 , 117-124

Perlack RD, Ranney JW, Barron WF, Cushman $\mathrm{JH}$, Trimble JL (1986) Short rotation intensive culture for the production of energy feedstocks in the US: a review of experimental results and remaining obstacles to commercialization. Biomass 9, 145-159

Pontailler JY, Leroux M, Saugier B (1984) Évolution d'un taillis de châtaigniers avant la coupe : photosynthèse et croissance des rejets. Acta Oecol Oecol Appl 5, 89-99 
Siren G, Sennerby-Forsse L, Ledin S (1987) Energy plantations-short rotation forestry in Sweden. In: Biomass - Regenerable Energy (Hall DO, Overend RP, eds) John Wiley and Sons, New York, 119-143

Stott KG (1956) Cultivation and uses of basket willows. Quart J For 14

Tschaplinski TJ, Blake TJ (1989a) Photosynthetic reinvigoration of leaves following shoot de- capitation and accelerated growth of coppice shoots. Physiol Plant 75, 157-165

Tschaplinski TJ, Blake TJ (1989b) The role of sink demand in carbon partitioning and photosynthetic reinvigoration following shoot decapitation. Physiol Plant 75, 166-173

Wright LL (1988) Are increased yields in coppice systems a myth? Bull Finn For Res Inst 304, 51-65 